\title{
Compliance with dietary guidelines in the Catalan population: basis for a nutrition policy at the regional level (the PAAS strategy)
}

\author{
Lluís Serra-Majem ${ }^{1,2,3, *}$, Lourdes Ribas-Barba ${ }^{1}, G$ Gemma Salvador ${ }^{3}$, Jaume Serra ${ }^{3}$, \\ Conxa Castell ${ }^{3}$, Carmen Cabezas ${ }^{3}$ and Antoni Plasencia ${ }^{3}$ \\ 'Community Nutrition Research Centre, University of Barcelona Science Park, Baldiri Reixac 4, Torre D 4A1, \\ 08028 Barcelona, Spain: ${ }^{2}$ Department of Clinical Sciences, University of Las Palmas de Gran Canaria, Las \\ Palmas de Gran Canaria, Spain: ${ }^{3}$ Division of Public Health, Department of Health, Generalitat of Catalonia, \\ Barcelona, Spain
}

Submitted 6 July 2007: Accepted 7 September 2007

\begin{abstract}
Objective: To analyse the degree of compliance with the nutrition objectives and population-based food guides and to indicate possible recommendations for their development within the framework of a Nutrition and Health Policy in Catalonia. Design: Using data derived from the latest Catalan Nutrition Survey (ENCAT 2002-03) conducted by the Department of Health, compliance was analysed with respect to the recommendations derived as a result of a previously conducted Survey. In addition, compliance to the recommendations elaborated by the Spanish Society of Community Nutrition (SENC) was also evaluated.

Setting: Catalonian region located in the Northeast of Spain.

Subjects: Analysis is based on a total of 2160 individuals (996 males and 1164 females) aged 10-80 years interviewed in 2002-03.

Results: The analysis of compliance with the recommendations established in 1995 showed: (a) recommendation to maintain and increase consumption of fruits and vegetables was not achieved; (b) continued use of olive oil as the dietary fat of choice was met; (c) incomplete compliance with maintaining the Mediterranean diet traditions, especially in the younger cohorts; (d) compliance with the recommendation to decrease consumption of red meat and sausages, but non-compliance with guidance to maintain or increase fish consumption and (e) compliance with partially substituting whole milk and dairy for low-fat products.

Compliance with the SENC Healthy Eating Guide revealed that those food groups with the worst results were meat and sausages (excessive), pulses (below recommendations) and fruits and vegetables (below recommendations).

Conclusions: Compliance with dietary guidelines is low in Catalonia, and reflects the need for an effective nutrition policy in the region defined by the Autonomous Government as the Plan for the Promotion of Physical Activity and Healthy Eating (PAAS).
\end{abstract}

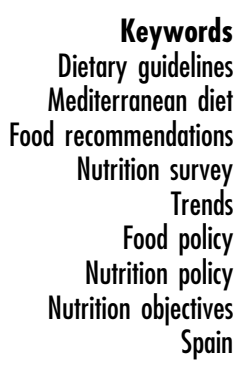

The results of the Catalan Nutrition Surveys (ENCAT 1992-93 and ENCAT 2002-03), described in detail in the six preceding articles ${ }^{1-6}$, have shed light on the principal nutrition problems in Catalonia. It thus seems necessary to analyse the degree of compliance with the populationbased nutrition objectives and food guides and to outline the possible recommendations to develop within the framework of a nutrition and health policy for Catalonia.

The dietary habits of a population are determining factors of its health status and moreover, are coupled with important economic and political repercussions. Inadequate eating habits (excessive, deficient or both) are associated with numerous pathologies having high mortality prevalence in the western world, such as cardiovascular diseases, certain cancers, obesity, osteoporosis, anaemia, dental caries, cataracts and specific immune disorders, among others ${ }^{7,8}$.

The Department of Health is the highest level health authority in Catalonia, an autonomous community with seven million inhabitants in the northeast of Spain. The activities on health promotion are among their main 
priorities. In this sense, and in agreement with the WHO strategy on Diet, Healthy Nutrition and Physical Activity, a Program (known as PAAS) for the promotion of health through balanced nutrition and physical activity has been developed. This program (PAAS) has different actions targeting a variety of settings: educational, health system, community and occupational.

Catalonia is well known at the national level and in Europe for its nutrition policies and actions, in addition to its system of evaluation and monitoring nutritional status? On the other hand, Catalonia has not been exempt from the changes in dietary habits that have affected developed countries. The evolution observed in western diets is characterised by a progressive increase in the consumption of foods of animal origin, the presence of large quantities of refined high-energy dense products, simultaneously accompanied by the low consumption of foods of vegetable origin. The nutritional translation of these changes has been manifest by increased energy intakes derived from total fat, trans and saturated fatty acids and sugars. In parallel, the decrease in the contributions of complex carbohydrates and vegetable proteins to the percent of total energy intake constitutes a general norm in modern societies. These dietary modifications are accompanied by important changes in living conditions, lifestyles and in a progressive decline in physical activity levels and energy expenditure derived from walking, work and thermal balance. Such dietary modifications, which characterise the transition of developing societies into developed ones, bring about an escalation of the previously mentioned non-communicable diseases ${ }^{8,10}$.

Modifying dietary habits and realising health promotion interventions in industrialised countries may be a task that is socially and politically difficult. While almost all these countries have a food policy in place, there are few who dispose of a nutrition policy ${ }^{11}$. The first is the result of legislation and governmental decisions directed towards assuring the provision of food for the population and encompass fiscal, commercial, political and social means, as well as consumer protection. As such, a food policy does not specifically take health into account, with the exception of assuring that a sufficient quantity of food is available and that the food supply is free of microbial contamination and toxic effects ${ }^{11}$. However, certain food policies explicitly consider nutritional aspects, and whatsmore, some countries that have Health Plans within the framework of public health and healthcare services do include nutrition objectives, programmes and activities ${ }^{12}$. The development of a nutrition policy that incorporates dietary guidelines or nutritional objectives that are in accordance with health promotion and food availability constitutes a fundamental aspect for all government authorities. In the case of Catalonia, the nutrition policy should be coherent and include legislation and directives of the Spanish and European government within the framework of its own Health Plan ${ }^{9,13-15}$.

\section{Material and methods}

\section{Sample}

Data were analysed drawing from the results of the 2002-03 Catalan Nutrition Survey (ENCAT 2002-03) ${ }^{16}$, a cross-sectional survey conducted in a representative sample of the Catalan population comprising 2160 individuals, aged 10-80 years (996 males and 1164 females). In order to evaluate selected recommendations, trends were analysed from the period 1992 to 2003 based on data from a previous Nutrition Survey (ENCAT 1992-93 $)^{17}$, which was realised in a sample of 2757 individuals aged 6-75 years. Both surveys utilised similar methodology for obtaining samples. For comparative analysis, the age cohorts analysed were between 10 and 75 years of age.

\section{Metbods}

Both surveys employed the same questionnaires and methods for assessing dietary habits: a food frequency questionnaire and two 24-hour recall conducted by trained dietitians in the homes of participating subjects, which have been described in previous articles of this monograph $^{1-6,16,17}$.

The level of compliance with the recommendations was determined by evaluating the trends that occurred between 1992 and 2003, taking into account the recommendations elaborated from the findings of the ENCAT 1992-93 $3^{17,18}$. Survey conclusions that were published and disseminated after 1995 included recommendations to: (a) maintain and increase the consumption of fruits and vegetables; (b) continue using olive oil as the dietary fat of choice; (c) maintain the Mediterranean diet traditions; (d) reduce the consumption of red meat and sausages, maintain or increase fish consumption and decrease total protein intake and (e) partially substitute whole milk and dairy products with low-fat alternatives, particularly in adults and the elderly ${ }^{17}$.

The evaluation of recommendations addressing specific foods, food groups and proteins was carried out analysing trends from 1992 to 2003 from food and nutrient consumption data obtained from the average of two 24 -hour recalls ${ }^{1,2}$. The recommendation for using olive oil as the dietary fat of choice was assessed by 1992-2003 trend data based on answers to the questionnaire addressing what kind of oil was commonly used for seasoning, cooking and frying foods ${ }^{16,17}$. To evaluate whether the population followed a Mediterranean Diet Model, responses to the following questions were considered: (1) the subject's assessment of the importance of 18 foods for defining the Mediterranean Diet and their rating of their degree of adherence to the Mediterranean $\operatorname{diet}^{16}$ and (2) the application of a Mediterranean Diet Adherence Index to reported consumption, which was developed for this purpose from data derived in the food 
frequency questionnaire as well as the alcoholic beverages frequency questionnaire. The detailed description of the elaboration of this instrument has been previously described $^{16}$. This index is based on the assessment of the usual consumption of the following 15 items: (1) fresh fruit and fruit juice, (2) vegetables, gazpacho and lettuce, (3) nuts and olives, (4) fish and pulses, (5) yoghurts and cheeses, (6) wine and cava (in persons under 18 years of age, this item was not included), (7) olive oil, (8) other oils, (9) bread, pasta and rice, (10) wholegrain bread, pasta and rice, (11) meats and sausages/coldcuts, (12) potatoes, (13) baked goods, cookies and sweets, (14) salted snacks and (15) alcoholic beverage consumption frequency. Higher or lower ratings were assigned to each item based on the tertile of consumption as well as on whether or not the item was considered as a characteristic component of the traditional Mediterranean Diet. The sum of the ratings yielded an index that rated from 0 to 100 the adherence to the Mediterranean Diet Pattern. The recodification of the index into tertiles allowed for the classification of adherence to the Mediterranean Diet as low, medium or high ${ }^{16}$.

Analysis also included compliance with the 1994 (updated in 2005) recommendations of the Spanish Society of Community Nutrition (SENC) ${ }^{19-21}$. This evaluation was based on specific age group data derived from the Food Frequency Questionnaires and assessed the percentage of the population that complied with each of the specific recommendations for each food group category.

\section{Results}

\section{Degree of compliance with recommendations}

In the conclusions of the previous Catalan Nutrition Survey (ENCAT 1992-93), ${ }^{17}$ it was determined that the dietary habits and consumption of energy and nutrients in Catalonia showed a model of consumption that was quite favourable and characteristic of Mediterranean countries. However, it was also recommended that these positive aspects had to be preserved and recuperated in those sectors in which they had been losing ground. As such, certain dietary recommendations were developed at that time.

Subsequently a decade later, based on data from the current Nutrition Survey of the Catalan population (ENCAT 2002-03), the degree of compliance for each one of these dietary recommendations was analysed.

1. 'Positive' dietary recommendations:

a) Maintain and increase the consumption of fruits and vegetables, a highly positive characteristic of Catalan diets, which should be promoted and especially so in the youngest age groups.

Table 1 compares fruit and vegetable consumption between the two nutrition surveys ENCAT 1992-93 and ENCAT 2002-03 by age group and gender. A decline in fruit consumption was observed, which was only partially compensated by increased intakes of fruit juices and nectars. A slight decrease was also seen in vegetable consumption in both men and women. For this reason, this recommendation has not been achieved.

b) Continue using olive oil as the dietary fat of choice, both for seasoning and in food preparation.

An increased use of olive oil was observed for both seasoning and cooking, and as such, demonstrates compliance with this recommendation (Fig. 1).

c) Maintain the traditional aspects of the Mediterranean Diet, recapturing dishes, recipes and traditional customs.

In order to follow-up on complaince with this recommendation, an index of adherence to the Mediterranean Diet Index was developed, as shown in Figure 2. Although this index does not reflect trends, its analysis revealed that the promotion of the Mediterranean Diet is especially critical for the younger generations, independent of gender or socio-economic level (data not shown).

The evaluation of knowledge in relation to the Mediterranean Diet showed that Catalans identified the following foods as essential to the Mediterranean Diet: fish, vegetables, salads, fruit and olive oil. For nuts, pulses, wine, bread and yoghurt, there were lower percentages of the sample citing them as key elements. Baked goods, beer and sunflower oil were not identified as components of the Mediterranean Diet (Fig. 3).

Sixty-three per cent of the population considered that they often $(42 \%)$ or very often $(21 \%)$ followed the Mediterranean Diet. However, when the Mediterranean Diet Adherence Index was applied, only $52 \%$ of the sample had a rating of 'good' or 'excellent' adherence to the Mediterranean Diet. This percentage improved with age (25\% of those between 10- and 17-year-old vs. more than $85 \%$ in those 65 years or older).

2. 'Dissuasive' dietary recommendations:

a) Reduce the consumption of meat, especially red meat and sausages/coldcuts, and maintain or increase fish consumption. Decreased protein intakes should be applied to the population as a whole.

Table 2 demonstrates the trends in the consumption of meat, fish, sausages/coldcuts and proteins in general for Catalonia. On the whole, compliance with the recommendation to reduce meat and protein foods and, to a lesser degree, sausages/ coldcuts was observed. However, the recommendation to increase fish consumption was not achieved, which showed a $15 \%$ decrease in the time period observed (being more pronounced in men than in women). 
Table 1 Variation in vegetable and fruit intakes in Catalonia 1992-2003

\begin{tabular}{|c|c|c|c|c|c|c|c|c|}
\hline \multirow[b]{2}{*}{ Gender } & \multirow[b]{2}{*}{ Food group } & \multirow[b]{2}{*}{$\begin{array}{c}\text { ENCAT Survey } \\
\text { Variation }\end{array}$} & \multicolumn{5}{|c|}{ Age group (years) } & \multirow[b]{2}{*}{$\begin{array}{l}\text { Total } \\
\text { Mean }\end{array}$} \\
\hline & & & $\begin{array}{l}10-17 \\
\text { Mean }\end{array}$ & $\begin{array}{l}18-24 \\
\text { Mean }\end{array}$ & $\begin{array}{l}25-44 \\
\text { Mean }\end{array}$ & $\begin{array}{l}45-64 \\
\text { Mean }\end{array}$ & $\begin{array}{l}65-75 \\
\text { Mean }\end{array}$ & \\
\hline \multirow[t]{9}{*}{ Males } & Vegetables (g/day) & $2002-03$ & 117.6 & 151.3 & 176.6 & 213.5 & 186.8 & 179.0 \\
\hline & Fruits (g/day) & $2002-03$ & 142.5 & 147.8 & 194.9 & 278.3 & 315.1 & 220.0 \\
\hline & Commercial juices and nectars ( $\mathrm{g} /$ day) & $2002-03$ & 55.2 & 55.3 & 47.2 & 20.6 & 21.9 & 38.9 \\
\hline & Vegetables (g/day) & 1992-93 & 116.6 & 164.3 & 198.5 & 220.5 & 224.3 & 193.9 \\
\hline & Fruits (g/day) & 1992-93 & 197.6 & 253.3 & 240.7 & 365.2 & 363.2 & 287.4 \\
\hline & Commercial juices and nectars (g/day) & 1992-93 & 32.3 & 46.8 & 20.6 & 7.7 & 4.5 & 20.0 \\
\hline & Vegetables (\%) & Variation & 0.9 & -7.9 & -11.1 & -3.2 & -16.7 & -7.7 \\
\hline & Fruits (\%) & Variation & -27.9 & -41.7 & -19.0 & -23.8 & -13.2 & -23.4 \\
\hline & Commercial juices and nectars (\%) & Variation & 70.8 & 18.2 & 129.5 & 168.8 & 388.1 & 94.7 \\
\hline \multirow[t]{9}{*}{ Females } & Vegetables (g/day) & 2002-03 & 129.1 & 154.8 & 193.8 & 230.2 & 183.8 & 193.2 \\
\hline & Fruits (g/day) & 2002-03 & 146.0 & 134.2 & 203.3 & 310.2 & 312.9 & 233.6 \\
\hline & Commercial juices and nectars (g/day) & 2002-03 & 57.9 & 46.6 & 33.0 & 18.6 & 6.5 & 29.3 \\
\hline & Vegetables (g/day) & 1992-93 & 141.6 & 163.7 & 218.3 & 231.1 & 215.4 & 206.6 \\
\hline & Fruits (g/day) & 1992-93 & 191.0 & 220.4 & 299.4 & 378.7 & 384.9 & 314.0 \\
\hline & Commercial juices and nectars ( $\mathrm{g} /$ day) & 1992-93 & 21.7 & 31.5 & 14.1 & 12.3 & 6.3 & 15.4 \\
\hline & Vegetables (\%) & Variation & -8.9 & -5.4 & -11.2 & -0.4 & -14.7 & -6.5 \\
\hline & Fruits (\%) & Variation & -23.6 & -39.1 & -32.1 & -18.1 & -18.7 & -25.6 \\
\hline & Commercial juices and nectars (\%) & Variation & 167.5 & 48.0 & 133.4 & 51.1 & 3.3 & 89.7 \\
\hline \multirow[t]{9}{*}{ Total } & Vegetables (g/day) & 2002-03 & 122.2 & 153.2 & 185.1 & 222.0 & 185.2 & 186.1 \\
\hline & Fruits (g/day) & 2002-03 & 143.9 & 140.4 & 199.0 & 294.5 & 313.9 & 226.8 \\
\hline & Commercial juices and nectars (g/day) & $2002-03$ & 56.3 & 50.6 & 40.2 & 19.6 & 13.7 & 34.1 \\
\hline & Vegetables (g/day) & 1992-93 & 128.1 & 164.0 & 208.4 & 225.9 & 219.3 & 200.4 \\
\hline & Fruits (g/day) & 1992-93 & 194.6 & 236.6 & 270.0 & 372.1 & 375.4 & 301.0 \\
\hline & Commercial juices and nectars ( $\mathrm{g} /$ day) & 1992-93 & 27.4 & 39.0 & 17.4 & 10.0 & 5.5 & 17.7 \\
\hline & Vegetables (\%) & Variation & -4.6 & -6.6 & -11.2 & -1.7 & -15.5 & -7.1 \\
\hline & Fruits (\%) & Variation & -26.0 & -40.7 & -26.3 & -20.9 & -16.4 & -24.6 \\
\hline & Commercial juices and nectars (\%) & Variation & 105.4 & 29.6 & 131.6 & 95.1 & 149.8 & 93.0 \\
\hline
\end{tabular}

Variation= (ENCAT 2002-03 - ENCAT 1992-93); *100/ENCAT 1992-93.

$\square$ Olive oil, virgin $\square$ Olive oil, refined $\square$ Sunflower oil $\square$ Other oils and fats

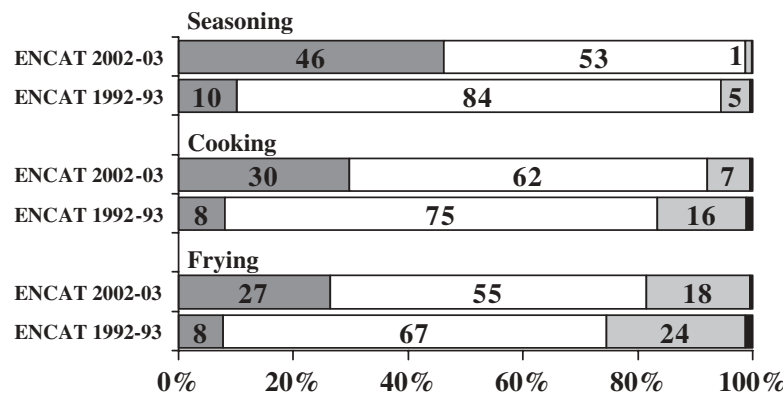

Fig. 1 Type of fat used for frying, cooking and seasoning in Catalonia. ENCAT 1992-93 and ENCAT 2002-03

b) Reduce or partially substitute the consumption of whole-fat milk and dairy products with low-fat products, especially among adults and the elderly. An overall rising trend in milk and dairy product consumption was noted, with a significant increase in skim milk product intakes (Fig. 4). As such, the trend for improved rates of low-fat dairy consumption was confirmed.

3. Avoid unnecessary vitamin and mineral supplementation. The best way to promote health is through the

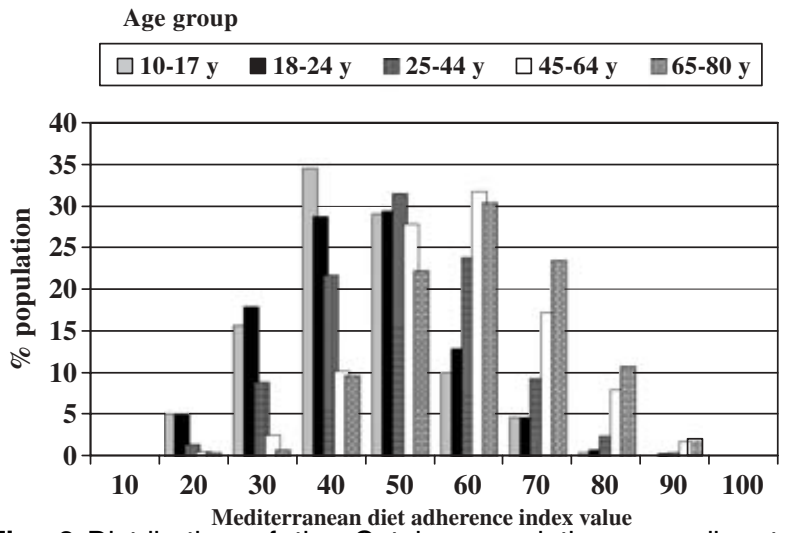

Fig. 2 Distribution of the Catalan population according to Mediterranean Diet adherence and age group. ENCAT 2002-03

dietary variety and balance that is naturally provided by our geographic and climatic environment. There are only a few cases that may warrant the need for supplementation as prescribed by a healthcare professional.

In general, there was no observed increase in the consumption of vitamin and mineral supplements (9\% in $1992-93$ and $8 \%$ in 2002-03) ${ }^{6}$. 


\section{Compliance with the population-based food guides (SENC)}

The evaluation of the degree that the recommended population-based food guides were followed (Table 3) shows that $30 \%$ of the population did not comply with the recommendation for fish consumption (3-4 servings week $\left.{ }^{-1}\right), \quad 68 \%$ exceeded the recommended meat/protein intake (3-4 servings week ${ }^{-1}$ ) and $7 \%$ exceeded the recommended egg intake (3-4 servings week $\left.{ }^{-1}\right)$. Sixty-three per cent did not meet the recommendation for pulses (2-4 servings week ${ }^{-1}$ ) and $74 \%$ showed noncompliance with the recommendation for nut consumption (3-7 servings week ${ }^{-1}$ ). Sixty-eight per cent met the recommendations for dairy products (2-4 servings day $\left.{ }^{-1}\right)(28 \%$ with inadequate and $4 \%$ with excessive intakes) and 49\% showed adequate intakes of

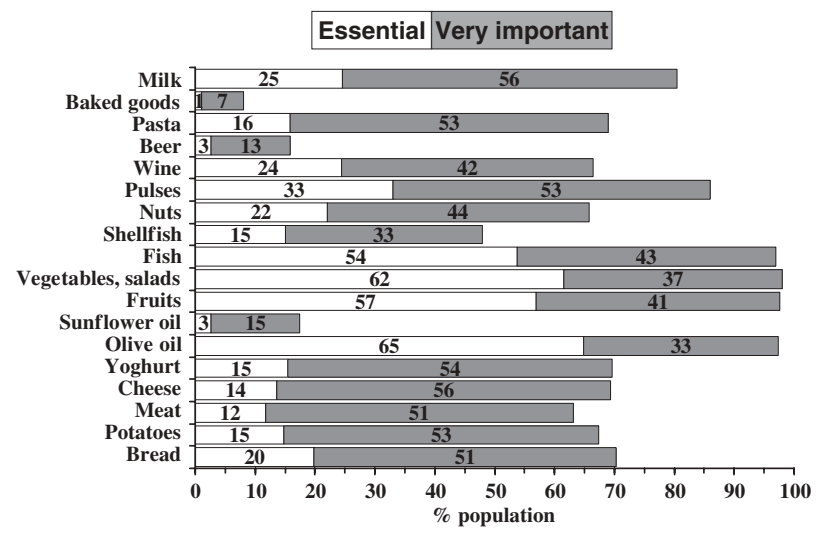

Fig. 3 Foods considered as essential or very important components of the Mediterranean Diet. ENCAT 2002-03 olive oil (3-6 servings day ${ }^{-1}$ ). Only $42 \%$ of the sample met recommendations for vegetable consumption $(\geq 2$ servings day $\left.{ }^{-1}\right)$ and only $26 \%$ met those for fruit $(\geq 3$ servings day ${ }^{-1}$ ).

Excess consumption was noted for recommended intakes of alcoholic beverages ( 0 servings for those under 18 -year-old and $<2$ servings day ${ }^{-1}$ in adults), animal fat $\left(<4\right.$ servings week $\left.{ }^{-1}\right)$, candy and sweets $(\leq 2$ servings day $\left.^{-1}\right)$, high-fat baked goods $\left(<4\right.$ servings week $\left.{ }^{-1}\right)$, softdrinks $\left(<1\right.$ serving day $\left.{ }^{-1}\right)$ and fatty meat and sausages/coldcuts $\left(<3\right.$ servings week $\left.{ }^{-1}\right)$ with the following $17 \%, 24 \%, 33 \%, 20 \%, 22 \%$ and $56 \%$ of the population, respectively. Notable differences were observed for the different age cohorts (Table 3).

\section{Discussion}

Nutrition objectives and food guides are evidence based and generally established by consensus by International Institutions or Scientific Societies. In Spain the nutrition objectives and, as a consequence, the food guides were developed by the SENC and have been widely distributed and published ${ }^{19-24}$.

As such, the definition of a prudent diet should be based on current knowledge of the relationship between nutrition and health. Moreover, this should more specifically be derived from the evaluation of food consumption of those population subgroups that are closest to what is nutritionally desirable, after having prioritised the nutritional problems of the target community ${ }^{25}$.

Various indexes are available to evaluate the degree of adherence to the Mediterranean $\operatorname{Diet}^{26}$, which is in fact an

Table 2 Variation in meat, fish and protein intake 1992-2003

\begin{tabular}{|c|c|c|c|c|c|c|c|}
\hline \multirow[b]{2}{*}{ Food group } & \multirow[b]{2}{*}{$\begin{array}{c}\text { ENCAT Survey } \\
\text { Variation }\end{array}$} & \multicolumn{5}{|c|}{ Age group (years) } & \multirow[b]{2}{*}{$\begin{array}{l}\text { Total } \\
\text { Mean }\end{array}$} \\
\hline & & $\begin{array}{l}10-17 \\
\text { Mean }\end{array}$ & $\begin{array}{l}\text { 18-24 } \\
\text { Mean }\end{array}$ & $\begin{array}{l}25-44 \\
\text { Mean }\end{array}$ & $\begin{array}{l}45-64 \\
\text { Mean }\end{array}$ & $\begin{array}{l}65-75 \\
\text { Mean }\end{array}$ & \\
\hline Meats (g/day) & 2002-03 & 90.8 & 91.9 & 76.8 & 61.8 & 47.8 & 72.6 \\
\hline Sausages and ham (g/day) & 2002-03 & 43.8 & 39.4 & 35.8 & 27.4 & 19.7 & 32.8 \\
\hline Poultry (g/day) & 2002-03 & 40.8 & 33.8 & 48.7 & 45.0 & 35.8 & 43.1 \\
\hline Fish and seafood (g/day) & 2002-03 & 42.2 & 46.8 & 59.4 & 78.0 & 65.4 & 62.0 \\
\hline Proteins (g/day) & 2002-03 & 97.2 & 93.0 & 91.1 & 85.9 & 72.6 & 88.3 \\
\hline Proteins (\% energy) & 2002-03 & 17.5 & 18.2 & 19.1 & 20.0 & 19.9 & 19.2 \\
\hline Meats (g/day) & 1992-93 & 91.7 & 99.3 & 90.7 & 75.9 & 55.1 & 82.6 \\
\hline Sausages and ham (g/day) & 1992-93 & 51.2 & 45.2 & 35.9 & 24.7 & 21.0 & 33.5 \\
\hline Poultry (g/day) & 1992-93 & 52.4 & 54.6 & 54.2 & 52.2 & 55.7 & 53.8 \\
\hline Fish and seafood (g/day) & 1992-93 & 45.9 & 55.1 & 76.6 & 84.8 & 76.4 & 72.6 \\
\hline Proteins (g/day) & 1992-93 & 98.7 & 101.6 & 98.8 & 91.5 & 84.1 & 95.0 \\
\hline Proteins (\% energy) & 1992-93 & 17.7 & 18.8 & 20.4 & 21.7 & 21.3 & 20.4 \\
\hline Meats (\%) & Variation & -1.0 & -7.4 & -15.3 & -18.6 & -13.2 & -12.1 \\
\hline Sausages and ham (\%) & Variation & -14.6 & -12.9 & -0.3 & 11.2 & -6.5 & -2.2 \\
\hline Poultry (\%) & Variation & -22.2 & -38.2 & -10.2 & -13.9 & -35.7 & -19.9 \\
\hline Fish and seafood (\%) & Variation & -8.0 & -15.0 & -22.5 & -8.0 & -14.5 & -14.7 \\
\hline Proteins, g/day (\%) & Variation & -1.5 & -8.5 & -7.8 & -6.1 & -13.7 & -7.1 \\
\hline Proteins, \% energy (\%) & Variation & -1.1 & -3.2 & -6.4 & -7.8 & -6.6 & -5.9 \\
\hline
\end{tabular}

Variation=(ENCAT 2002-03 - ENCAT 1992-93); *100/ENCAT 1992-93. 


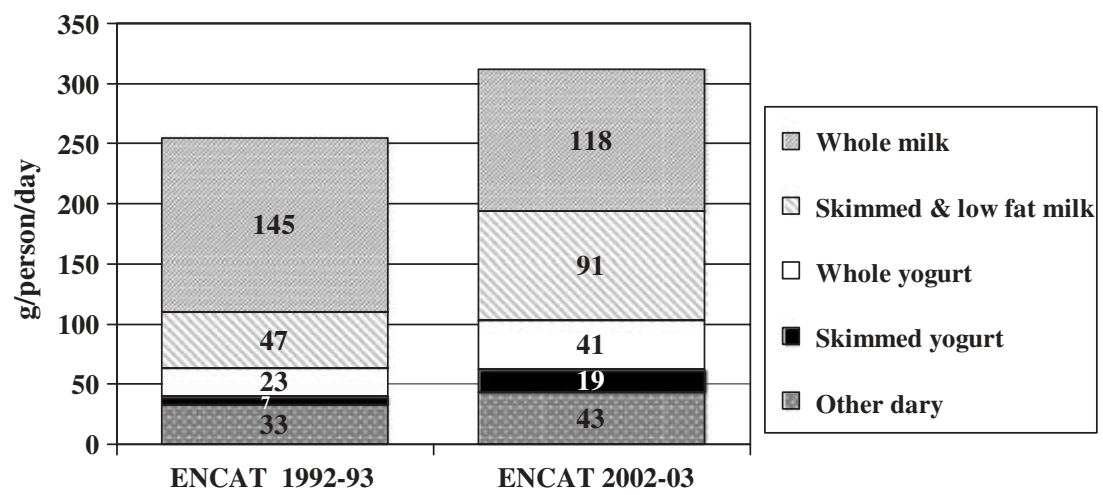

Fig. 4 Trends (1992-2003) in dairy product consumption in the Catalan population aged 10-75 years

Table 3 Level of compliance with the SENC recommendations for the Catalan population by age group (ENCAT 2002-03)

\begin{tabular}{|c|c|c|c|c|c|c|c|c|c|c|c|c|c|c|c|c|}
\hline \multirow[b]{3}{*}{ Fish (3-4 servings/week) } & \multicolumn{4}{|c|}{$\begin{array}{c}\text { Total sample } \\
\text { Intake }\end{array}$} & \multicolumn{4}{|c|}{$\begin{array}{l}\text { Age group: } 10-24 \text { years } \\
\text { Intake }\end{array}$} & \multicolumn{4}{|c|}{$\begin{array}{l}\text { Age group: } 25-64 \text { years } \\
\text { Intake }\end{array}$} & \multicolumn{4}{|c|}{$\begin{array}{c}\text { Age group: } 65 \text { and more years } \\
\text { Intake }\end{array}$} \\
\hline & \multirow{2}{*}{$\begin{array}{c}\text { Doesn't } \\
\text { eat }(\%)\end{array}$} & \multicolumn{3}{|c|}{$\begin{array}{c}\text { Less than } \mid \text { Equal to } \mid \text { Exceeds } \\
\text { recommended (\%) }\end{array}$} & \multirow{2}{*}{$\begin{array}{c}\begin{array}{c}\text { Doesn't } \\
\text { eat }(\%)\end{array} \\
1.8\end{array}$} & \multicolumn{3}{|c|}{\begin{tabular}{|c|c|} 
Less than & Equal to \\
recommended $(\%)$
\end{tabular}} & \multirow{2}{*}{$\begin{array}{c}\begin{array}{c}\text { Doesn't } \\
\text { eat }(\%)\end{array} \\
0.6\end{array}$} & \multicolumn{3}{|c|}{$\begin{array}{c}\text { Less than Equal to Exceeds } \\
\text { recommended (\%) }\end{array}$} & \multirow{2}{*}{$\begin{array}{c}\begin{array}{c}\text { Doesn't } \\
\text { eat }(\%)\end{array} \\
1.6\end{array}$} & \multicolumn{2}{|c|}{$\begin{array}{l}\text { Less than } \mid \text { Equal to } \\
\text { recommended }(\%\end{array}$} & $\begin{array}{l}\text { Exceeds } \\
\%) \\
\end{array}$ \\
\hline & & 28.3 & 37.9 & 32.8 & & 40.0 & 38.1 & 20.0 & & 24.8 & 37.5 & 37.0 & & 27.3 & 39.3 & 31.8 \\
\hline Lean meat (3-4 servings/week) & 1.0 & 7.4 & 23.7 & 67.9 & 0.6 & 6.7 & 20.3 & 72.4 & 1.0 & 5.4 & 22.7 & 70.8 & 1.6 & 16.3 & 32.1 & 49.9 \\
\hline Eggs (3-4 servings/week) & 2.7 & 68.9 & 21.1 & 7.2 & 1.8 & 67.5 & 23.7 & 6.9 & 3.0 & 67.2 & 21.8 & 7.9 & 2.8 & 78.1 & 14.4 & 4.7 \\
\hline Pulses (2-4 servings/week) & 4.9 & 58.1 & 35.3 & 1.7 & 7.1 & 58.3 & 33.7 & 1.0 & 4.6 & 58.1 & 35.4 & 1.9 & 3.2 & 57.9 & 37.2 & 1.7 \\
\hline Nuts (3-7 servings/week) & 28.9 & 45.1 & 19.2 & 6.8 & 36.1 & 45.7 & 13.1 & 5.2 & 25.6 & 46.4 & 20.4 & 7.6 & 33.3 & 38.6 & 22.6 & 5.5 \\
\hline Dairy (2-4 servings/day) & 0.4 & 27.3 & 68.0 & 4.3 & & 20.3 & 73.9 & 5.8 & 0.3 & 27.6 & 67.4 & 4.7 & 1.2 & 35.1 & 63.0 & 0.6 \\
\hline Olive oil (3-6 servings/day) & 1.6 & 44.4 & 49.1 & 4.9 & 1.7 & 43.8 & 50.1 & 4.4 & 1.4 & 42.9 & 50.5 & 5.2 & 2.2 & 51.7 & 41.8 & 4.3 \\
\hline Vegetables ( $\geq 2$ servings/day) & 0.3 & 57.6 & 42.1 & & 0.5 & 73.7 & 25.8 & & 0.1 & 53.3 & 46.5 & & 0.9 & 54.5 & 44.7 & \\
\hline Fruits ( $\geq 3$ servings/day) & 1.4 & 72.7 & 25.9 & & 0.9 & 85.0 & 14.0 & & 1.7 & 71.5 & 26.8 & & 0.9 & 61.4 & 37.7 & \\
\hline Fruits and juices ( $\geq 3$ servings/day) & 1.0 & 63.9 & 35.1 & & 0.4 & 70.2 & 29.4 & & 1.3 & 63.3 & 35.4 & & 0.9 & 57.7 & 41.4 & \\
\hline $\begin{array}{l}\text { Bread, rice, pasta, cereals, potatoes } \\
\text { (4-6 servings/day) }\end{array}$ & 0.0 & 14.0 & 60.6 & 25.4 & 0.0 & 7.6 & 53.0 & 39.4 & 0.0 & 15.0 & 62.4 & 22.5 & 0.0 & 18.0 & 63.2 & 18.8 \\
\hline Water (4-8 servings/day) & 1.0 & 33.6 & 57.7 & 7.6 & 0.7 & 27.4 & 63.0 & 8.9 & 1.0 & 34.5 & 56.7 & 7.7 & 2.4 & 37.5 & 54.5 & 5.6 \\
\hline $\begin{array}{l}\text { Wine, beer ( } 0 \text { servings for }<18 \text { years } \\
\text { and } \leq 1 \text { serving/day for } \geq 18 \text { years })\end{array}$ & 36.8 & & 46.6 & 16.6 & 59.2 & & 36.0 & 4.8 & 24.6 & & 55.1 & 20.3 & 40.2 & & 38.1 & 21.8 \\
\hline Fats ( $<4$ servings/week) & 40.1 & & 36.3 & 23.6 & 31.4 & & 42.1 & 26.5 & 38.5 & & 37.7 & 23.8 & 58.2 & & 22.9 & 18.9 \\
\hline Sugars ( $\leq 2$ servings/day) & 7.3 & & 59.1 & 33.5 & 1.6 & & 56.7 & 41.6 & 6.5 & & 59.6 & 33.8 & 20.4 & & 59.6 & 20.0 \\
\hline Baked goods ( $<3$ servings/week) & 27.8 & & 52.0 & 20.2 & 11.0 & & 59.2 & 29.8 & 26.2 & & 53.6 & 20.2 & 56.4 & & 36.1 & 7.5 \\
\hline $\begin{array}{l}\text { Carbonated beverages } \\
(<1 \text { servings/day) }\end{array}$ & 29.5 & & 48.8 & 21.8 & 12.4 & & 55.1 & 32.5 & 27.4 & & 50.9 & 21.8 & 60.8 & & 31.6 & 7.6 \\
\hline $\begin{array}{l}\text { Fatty meats and sausages } \\
(<3 \text { servings/week })\end{array}$ & 3.3 & & 40.6 & 56.1 & 2.2 & & 27.3 & 70.5 & 3.3 & & 39.7 & 57.0 & 4.5 & & 61.8 & 33.7 \\
\hline
\end{tabular}

Cells highlighted in grey denote population with excessively low or high intakes.

increasingly popular and current topic of interest. Without a doubt the results of this evaluation demonstrate that the Mediterranean Diet is losing ground, especially among the younger age groups. This underscores the need to prioritise initiatives and actions for its preservation and promotion.

Eating habits and the consumption of energy and nutrients in Catalonia present a model of consumption that is quite favourable, inherent to Mediterranean countries but with important differences according to age. The youngest age groups are the ones that have deviated the most from this model of healthy eating. For all these reasons, the earlier dietary guidelines are reinforced the better, focusing on the maintenance of positive habits and reducing undesirable eating trends.

The following are highlighted as current dietary guidelines for the Catalan population:

1. 'Positive' dietary recommendations:

- Increase consumption of fruits and vegetables, a positive aspect of the Catalan diet that should be promoted especially among children and youth.

- Increase consumption of wholegrain cereal and high fibre foods.

- Increase fish consumption, and particularly blue fish. 
- Continue using olive oil as the added oil of choice, both for seasoning and for cooking.

- Maintain the traditional characteristics of the Mediterranean Diet, emphasising the role of traditional dishes, recipes and customs.

2. The 'dissuasive' dietary recommendations are:

- Reduce consumption of meat and sausages/ coldcuts.

- Partially substitute whole milk and dairy products with low-fat milk and derivatives.

3. Avoid taking multivitamin supplements, as the best way of promoting health is to enjoy the varied and complete diet provided by our geoclimatic environment. There are only a few cases in which supplementation could be appropriate under medical prescription or advice. However, it is recommended to consider the possibilities of folate fortification for certain foods, and to promote iodised salt availability and consumption.

It is imperative to continue with the thorough analysis of the data collection obtained. This would allow for further insight into the determinants of nutritional status for certain vitamins and minerals. Moreover, it would be essential for facilitating the identification of population groups that are at greater risk for nutritional deficiencies or unbalanced intakes, which today are closely tied to socio-economic and cultural determinants.

The development of a nutrition policy for the Catalan population is warranted in which possible interventions would be identified as well as the context for managing policies within the EU directives and the Spanish agrofood policies. Objectives of this nutrition policy would be tailored to the food and culinary idiosyncrasies inherent to each health region. The foundation should be based on the promotion of the Mediterranean diet and a physically active lifestyle.

As the dietary guidelines, food guides and degree of compliance have been defined, the development of a Nutrition Policy for Catalonia involves the implementation of coordinated actions addressing: food availability, food quality and the demand for consumption by the population $^{25}$.

\section{Actions addressing food availability}

The promotion of healthy eating habits requires not only the modification via nutrition education of the demand for foods but also to guarantee food quality and availability. If food availability is not assured or adjusted, it is quite likely that educational interventions will fail to meet their objective of increasing population-based consumption of a specific food. Moreover, it just might increase the disparity between those who can consume the food and those who cannot. It would not do any good to promote vegetable consumption if we do not provide the means to increase its production and availability. For this reason, the access to or availability and the demand or consumption are intimately related. It is extremely difficult to affirm which precedes the other, but what can be firmly stated is that promoting consumption of any specific food requires that there is sufficient availability of the product $^{27}$.

\section{Actions addressing food quality}

In Catalonia, the food service sector is particularly taken into consideration, especially as it is extremely important to the tourist industry and determines to a great degree the image that Spain has for vacationers. Moreover, it represents a threat to public health in terms of potential sources of food poisoning or nutritionally unbalanced products (many establishments utilise undesirable fats, such as certain vegetable oils, for frying and cooking, and this may have negative health repercussions for those who are frequent consumers). Thus, this sector should be encouraged to be accountable and to cater to the demands of the European Community. Municipal governments, with the assistance of the Autonomous Government, should guarantee that this process takes place without undue reliance on police measures, but rather be fundamentally based on education and training. In this context, it is critical to develop training programmes for employees of this sector, which are integrated to other training and capacity building initiatives.

The food industry should also make an effort to improve its products in accordance with current nutrition knowledge, adjusting fat quality and food additives to benefit the health of those consuming their products. It is important to improve the quality and sensory qualities of certain products such as fruits, vegetables and fish with the aim of making them more attractive and appealing for the consumer. Developing Research and Development programmes is key for the food industry and university based research groups in Catalonia. Special mention should be made of the reduction of portion sizes.

\section{Educational actions targeting food demand}

Lastly, and within the context of nutrition education, there exists a need to determine those areas requiring immediate development of educational messages. To achieve this, considerable analysis is necessary that takes into account: (1) the existing scientific bases for recommending dietary changes in the target population or specific subgroups; (2) the availability and barriers of the local, national and international food markets; (3) the consumer's internalisation of the need for dietary change, which is subject to deeply rooted food preferences and habits and (4) the exhaustive and meticulous knowledge of the problem within the population at an epidemiological level. In Catalonia, we have access to sufficient information so as to address the previously exposed factors. 
Notable experiences in programmes promoting healthy eating in different settings have taken place in Catalonia: in schools, homes, social settings, pharmacies and the worksite, although not all have been duly evaluated and published. These kinds of programmes require the participation and collaboration of a variety of sectors and key players in the food chain. For this reason, a multidisciplinary organisational approach is needed that involves food manufacturers, distributors, retailers, mass media and even consumers themselves and their social network. The umbrella of this holistic strategy is the PAAS Programme ${ }^{28}$, which is summarised as follows.

\section{The PAAS Programme}

PAAS stands for the 'Plan for the Promotion of Physical Activity and Healthy Eating'.

A priority objective of the Catalan Health Department is to promote and to protect health through the establishment of integrated policies and plans. Their aim is to improve the dietary habits and to promote being physically active on a regular basis, within the cultural context of a Mediterranean lifestyle that facilitates the autonomy of individuals.

The Global Strategy on Diet, Physical Activity and Health, approved by the 57 th World Health Assembly in May $2004^{29}$, has as its main objective to facilitate creating and enabling environments for sustainable actions at the individual, community, national and global levels that, when taken together, will lead to reduced disease and death rates related to unhealthy diet and lack of physical activity.

In this context, the Catalan Health Department was aware of the wide scope of a strategy such as that recommended by $\mathrm{WHO}^{29}$, which discouraged any intervention that was limited to only one area of action. Moreover, the strategy's emphasis on programmes of pluridisciplinary and multisectorial natures led to the development of the Integrated Plan for the Promotion of PAAS. This holistic initiative promoted the creation of coalitions and community action among various stakeholders - government bodies, local organisations and the civil society.

PAAS proposals include the following:

- To develop informational and educational actions as well as interventions on environmental determinants focusing on lifestyle factors.

- To increase the population's consciousness of the need for perceiving the health promoting options of healthy eating and physical activity as something within their reach.

- To promote agreements and commitments in different settings that potentiate collaborative strategies with the aim of enhancing the efficiency of utilising existing resources.
Areas of action:

- Educational setting: an example of an initiative in this framework: the monitoring of menu planning in Catalan schools. During the academic year 2006-07, 280 evaluations were conducted.

- Healthcare setting: an example of an initiative in this area: Monographic courses and seminars on food and nutrition directed towards primary healthcare professionals. During 2006-07, 11 courses were conducted with approximately 275 participating professionals.

- Worksite setting: an example of an initiative in this setting: The Stairway Project, developed by the Health Department. Currently in process of expansion to all the Departments of the Catalan government, the Generalitat de Catalunya.

- Community setting: an example of an initiative in this area: Project AMED, restaurants that officially promote the Mediterranean Diet. In 2007, a pilot was conducted in Granollers (more information at www.amed.cat).

\section{Acknowledgements}

Source of funding: This work was made possible by financing from the General Division of Public Health of the Generalitat of Catalonia's Department of Health, through a research agreement with the Fundación para la Investigación Nutricional (Nutrition Research Foundation).

Conflict of interest: None of the authors had any conflicts of interest in connection with this study.

Authorship responsibilities: LSM was director of the study, and was responsible for the interpretation of dietary data and the writing of the paper; LRB was responsible for the statistical analysis and revised paper providing expert advice in the discussion; GS and CC participated in the study concept and design and revised the paper providing expert advice in the discussion of the paper; JS, CC and AP provided expert advice in the discussion of the paper.

Guarantor: Lluís Serra-Majem.

Acknowledgements: Special acknowledgement is made to all those persons who were interviewed, and whose collaboration made the realisation of these surveys possible.

Research Group on the Evaluation and Monitoring of the Nutritional Status in the Catalan Population: Lluís SerraMajem, Director (University of Las Palmas de Gran Canaria); Lourdes Ribas-Barba, Coordinator (FIN-Nutrition Research Foundation-, Barcelona Science Park); Gemma Salvador (Generalitat of Catalonia); Conxa Castell (Generalitat of Catalonia); Blanca Román- Viñas (FIN, Barcelona Science Park); Jaume Serra (Generalitat of Catalonia); Lluís Jover (University of Barcelona); Ricard Tresserras (Generalitat of Catalonia); Blanca Raidó (FIN, Barcelona Science Park); Andreu Farran (CESNID, University of Barcelona); 
Joy Ngo (FIN, Barcelona Science Park); Mari Cruz Pastor (Hospital Germans Trias i Pujol, Badalona); Lluís Salleras (University of Barcelona); and Carmen Cabezas, Josep Lluís Taberner, Salvi Juncà, Josep Maria Aragay, Eulàlia Roure, Gonçal Lloveras Vallès († 2003), Antoni Plasencia (Generalitat of Catalonia).

\section{References}

1 Ribas-Barba L, Serra-Majem L, Salvador G, Castell C, Cabezas C, Salleras L, et al. Trends in dietary habits and food consumption in Catalonia, Spain (1992-2003). Public Health Nutrition 2007; 10(11A): 1340-53.

2 Serra-Majem L, Ribas-Barba L, Salvador G, Jover L, Raidó B, $\mathrm{Ngo} \mathrm{J}$, et al. Trends in energy and nutrient intake and risk of inadequate intakes in Catalonia, Spain (1992-2003). Public Health Nutrition 2007; 10(11A): 1368-78.

3 García-Álvarez A, Serra-Majem L, Ribas-Barba L, Castell C, Foz M, Uauy R, et al. Obesity and overweight trends in Catalonia, Spain (1992-2003). Gender and socioeconomic determinants. Public Health Nutrition 2007 (in this issue).

4 Serra-Majem L, Pastor-Ferrer MC, Castell C, Ribas-Barba L, Román-Viñas B, Font Ribera L, et al. Trends in blood lipids and fat soluble vitamins in Catalonia, Spain (1992-2003). Public Health Nutrition 2007; 10(11A): 1379-88.

5 Román-Viñas B, Serra-Majem L, Ribas-Barba L, RoureCuspinera E, Cabezas C, Vallbona C, et al. Trends in physical activity status in Catalonia, Spain (1992-2003). Public Health Nutrition 2007; 10(11A): 1389-95.

6 Serra-Majem L, Román-Viñas B, Salvador G, Ribas-Barba L, Ngo J, Castell C, et al. Knowledge, opinions and behaviours related to food and nutrition in Catalonia, Spain (1992-2003). Public Health Nutrition 2007; 10(11A): 1396-405.

7 World Health Organization. Diet, Nutrition and the Prevention of Chronic Diseases. Report of a Joint Food and Agriculture Organization of the United Nations/World Health Organization Expert consultation. World Health Organization Technical Report Series 916. Genève: WHO, 2003.

8 Kennedy ET. Evidence for nutritional benefits in prolonging wellness. American Journal of Clinical Nutrition 2006; 83 : 410S-4S.

9 Salleras L, Lloveras G, Serra-Majem L. Nutrition in the health policy context of Catalonia. European Journal of Clinical Nutrition 1993; 47(Suppl. 1): s1-3.

10 Popkin BM. Global nutrition dynamics: the world is shifting rapidly toward a diet linked with noncommunicable diseases. American Journal of Clinical Nutrition 2006; 84(2): 289-98.

11 Ortíz Moncada MR, Serra Majem L. Políticas de nutrición. In: Serra Majem L, Aranceta Bartrina J, eds. Nutrición y Salud Pública. Métodos, Bases científicas y Aplicaciones, second edition. Barcelona: Masson, 2006; 666-75.

12 Lachat C, Van Camp J, De Henauw S, Matthys C, Larondelle $\mathrm{Y}$, Remaut-De Winter AM, et al. A concise overview of national nutrition action plans in the European Union Member States. Public Health Nutrition 2005; 8(3): 266-74.

13 Serra-Majem L, Ferro-Luzzi A, Bellizzi MC, Salleras L. Nutrition policies in Mediterranean Europe. Nutrition Reviews 1997; 55(Suppl. II): s42-57.

14 Serra Majem L, Ribas L, Lloveras G, Salleras L. A nutritional policy at regional level: the Catalonia case study.
In: Wheelock V, ed. Implementing Dietary Guidelines for Healthy Eating. London: Chapman \& Hall, 1997; 291-301.

15 Generalitat de Catalunya. Departament de Sanitat $i$ Seguretat Social. Estratègies de salut. Pla de salut de Catalunya 2002-2005. Barcelona: Departament de Sanitat i Seguretat Social, 2003.

16 Serra Majem L, Ribas Barba L, Salvador Castell G, Castell Abat C, Román Viñas B, Serra Farró J, et al. Avaluació de l'estat nutricional de la població catalana 2002-2003. Evolució dels hàbits alimentaris $i$ dels consum d'aliments $i$ nutrients a Catalunya (1992-2003). Barcelona: Departament de Salut, Generalitat de Catalunya, 2006.

17 Serra Majem L, Ribas Barba L, García Closas R, Ramon JM, Salvador G, Farran A, et al. Llibre Blanc: Avaluació de l'estat nutricional de la població catalana (1992-93). Barcelona: Departament de Sanitat i Seguretat Social, Generalitat de Catalunya, 1996; 1-252.

18 Serra-Majem LL, Ribas L, Ramon JM. Compliance with dietary guidelines in the Spanish population. Results from the Catalan Nutrition Survey. British Journal of Nutrition 1999; 81(Suppl. 2): s105-s12.

19 Serra Majem L, Aranceta J, Mataix J. Documento de consenso: guías alimentarias para la población española. Barcelona: SG-Editores, 1995.

20 Aranceta J, Serra-Majem L, on behalf of the Working Party for the Development of Food-Based Dietary Guidelines for the Spanish Population. Dietary guidelines for the Spanish population. Public Health Nutrition 2001; 4(6A): 1403-8.

21 Dapcich V, Salvador G, Ribas L, Pérez Rodrigo C, Aranceta J, Serra Majem L. Guia de la Alimentación saludable. Madrid: SENC-Everest, 2005; 1-07.

22 Serra-Majem L, Aranceta J, on behalf of the SENC Working Group on Nutritiuonal Objectives for the Spanish Population. Nutritional objectives for the Spanish population. Consensus from the Spanish Society of Community Nutrition. Public Health Nutrition 2001; 4(6A): 1409-13.

23 Sociedad Española de Nutrición Comunitaria (SENC). Guias Alimentarias para la Población Española: recomendaciones para una dieta saludable. Madrid: IM\&C, S.A., 2001; 1-502.

24 Serra Majem L, Aranceta J, Group of Nutrition Guidelines of the Spanish Society of Community Nutrition. Nutrition and dietary guidelines for the Spanish population. Tool for a nutrition policy in Spain. In: Wheelock V, ed. Implementing Dietary Guidelines for Healthy Eating. Londres: Chapman \& Hall, 1997; 233-44.

25 Serra Majem L. Dietary guidelines: the prudent diet. In: Varela. Xacobeo Decalogue on Diet in the 21st Century. Madrid: Fundación Española de la Nutrición, 2000; 143-58.

26 Bach A, Serra-Majem L, Carrasco JL, Roman B, Ngo J, Bertomeu I, et al. The use of indexes evaluating the adherence to the Mediterranean diet in epidemiological studies: a review. Public Health Nutrition 2006; 9(1A): 132-46.

27 Wheelock V, ed. Implementing Dietary Guidelines for Healthy Eating. Londres: Chapman \& Hall 1997.

28 Departament de Salut, Generalitat de Catalunya. Pla integral per a la promocio de la salut mitjançant l'activitat física i l'alimentació saludables(PAAS). Barcelona, Generalitat de Catalunya, 2006. Available at http://www.gencat. net/salut/depsan/units/sanitat/pdf/paas.pdf. Accessed 3 May 2007.

29 Worlh Health Organization. World Strategy On Diet, Phisical Activity and Health. Geneva: WHO, 2004. Available at http://www.who.int/gb/ebwha/pdf_files/WHA57/A57_ R17-en.pdf. Accessed 3 may 2007. 